\title{
Fruit removal of a wild tomato, Solanum granulosoleprosum Dunal (Solanaceae), by birds, bats and non-flying mammals in an urban Brazilian environment
}

\author{
Nilton Carlos Cáceres ${ }^{1} \&$ Maurício Osvaldo Moura ${ }^{2}$ \\ ${ }^{1}$ Departamento de Biociências, Universidade Federal do Mato Grosso do Sul. Caixa Postal 051, 79200-000 Aquidauana, \\ Mato Grosso do Sul, Brasil. E-mail: nc_caceres@hotmail.com \\ ${ }^{2}$ Departamento de Ciências Biológicas, Universidade Estadual do Centro Oeste. 85010-090 Guarapuava, Paraná, Brasil. E- \\ mail: moura@unicentro.br
}

\begin{abstract}
A study of removal of fruits of the wild tomato, Solanum granulosoleprosum Dunal ( $\mathrm{N}=5$ plants), by vertebrates was carried out in an urban environment of southern Brazil from January to May 1997 and February 1998. To verify diurnal and nocturnal removals, fruits were counted in several fruit bunches, being classified by size and color. Diurnal observations were made on plants to verify bird removal. A mist net was placed among the plants from the evening to $23: 00 \mathrm{~h}$ to verify bat consumption. Live traps baited with $S$. granulosoleprosum fruits were placed on the ground among plants to verify terrestrial removers. On average it was found two ripe fruits available per bunch/day, but unripe, small, fruits were dominant (70\%). Nocturnal mammals and birdsdiurnal mammals partitioned fruits similarly. Bats removing fruits were Artibeus lituratus (Olfers, 1818), Pygoderma bilabiatum (Wagner, 1843) and Sturnira lilium (E. Geoffroy, 1810). Birds were Saltator similis Lafresnaye \& d'Orbigny, 1837 and Thraupis sayaca (Linnaeus, 1766). Terrestrial mammals were a marsupial and three rodent species. Except for rodents, these vertebrates must be promoting the seed dispersal of $S$. granulosoleprosum seeds in disturbed mixed forests of southern Brazil.
\end{abstract}

KEY WORDS Aves, food partitioning, fructification pattern, frugivory, Mammalia, seed dispersal.

Fleshy fruits dispersed by animals, known as zoochoric fruits, are the main dispersal devices utilized by plants in tropical regions (SMithe 1970, Howe \& SMallwood 1982). The chiropterochory and the ornitochory are two of the main zoochoric syndromes for seed dispersal (VAN DER PIJL 1982). However, some hosts of seed dispersers do not belong strongly to any syndrome and others belong equally to two or more syndromes rather than to only one. Herein, this study was carried out with a clumped population of a pioneer plant, the wild tomato Solanum granulosoleprosum Dunal (Solanaceae) (Fig. 1), to determine its fruit removal rate, and what are its vertebrate seed dispersers.

The study area was a gap located in a disturbed, urban, environment composed of pioneer plants. It was $60 \mathrm{~m}$ apart from a secondary mixed ombrophyllous forest fragment and was $20 \mathrm{~m}$ apart of the Sector of Biological Sciences of the Federal University of Paraná (UFPR, Curitiba, Paraná). Five out of 14 clumped individuals of $S$. granulosoleprosum were studied. Their height averaged $2 \mathrm{~m}$. A voucher material of the plants was deposited in the botanical museum (UPCB 30680) of the UFPR. Other main plants found with $S$. granulosoleprosum were
Rubus rosifolium Stokes (Rosaceae) (Fig. 1), Vassobia breviflora (Sendtn.) Munz. (Solanaceae), Physalis pubescens Linnaeus (Solanaceae) and Lantana camara L. (Verbenaceae). Fruits of $S$. granulosoleprosum were found in bunches (or racemoses) exposed outside dense crown (Fig. 1). Flowers and fruits at different degrees of development might be found in the same fruit bunch.

The overall study on plants was carried out from January to May 1997. In order to search diurnal and nocturnal removal rates, fruits were marked and daily counted in several bunches of five plants, being classified by size (small: $1.0-1.3 \mathrm{~cm}$, medium: 1.4-1.6 cm, big: $>1.6 \mathrm{~cm}$ ), color (green or mostly immature; yellowish or ripe) and sign of predation (usually by beetles, grasshoppers and ants), and re-counted in the morning (for nocturnal vertebrate removal) and in the evening (for bird removal), consecutively for at least $48 \mathrm{~h}$ each phase (four nocturnal and three diurnal phases). Differences seen were tested using the test of proportions based on different sample sizes (STATISTICA 1993). To search the ripe fruit availability per day (this intended as yellowish fruits), several bunches of five plants were randomly sampled during four different days (at least two weeks of interval). To verify the rate of fruit fall be- 

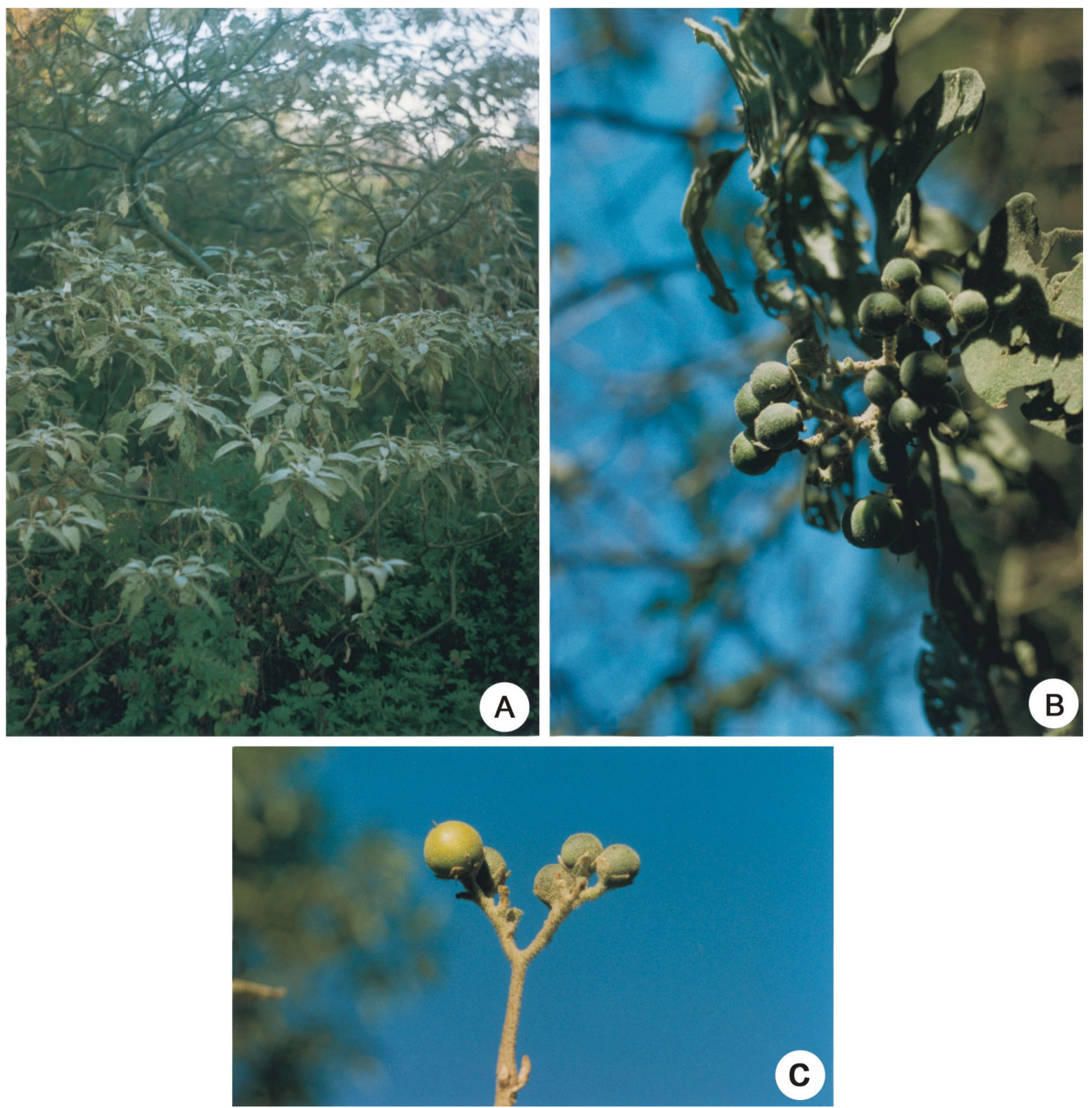

Figures 1-3. (1) Gap showing two individuals of the wild tomato, Solanum granulosoleprosum (in the center and above), and Rubus rosifolium (below). (2) Immature fruit bunch of $S$. granulosoleprosum with dominance of unripe small and median sized-fruits. (3) Mature bunch with the last fruits but showing the general feature observed on plants: one big-yellowish fruit and the remaining smaller, green ones. Photographed by N.C. Cáceres.

low plants, three square areas of $1 \mathrm{~m}^{2}$ were marked below each plant and fallen fruits were counted there.

Bird species feeding on $S$. granulosoleprosum were daily monitored with binoculars during 08:00-10:00 $\mathrm{h}$ and 15:30$17: 30 \mathrm{~h}(\mathrm{~N}=14 \mathrm{~h})$. Also a mist net of $2.5 \mathrm{~m}$ in height and $9 \mathrm{~m}$ in length was placed among the plants from the evening to about 23:00 h to verify bat removal ( $\mathrm{N}=20 \mathrm{~h} ; 5$ non-consecutive nights). Some live traps ( $\mathrm{N}=5$ to 10$)$ of two sizes ( $40 \times 20$ $\mathrm{x} 20 \mathrm{~cm}$ and $20 \times 10 \times 10 \mathrm{~cm}$ ), baited with $S$. granulosoleprosum fruits, were also placed on the ground among plants. All animal observations were made during February to May 1997 but also during February 1998.

A few ripe fruits of $S$. granulosoleprosum become available for consumption every $24 \mathrm{~h}$ (averaging 1.8 yellowish fruit per bunch, $\mathrm{N}=28$ different bunches sampled). All fruits monitored in bunches for this last result were big (61\%) or of median (39\%) sizes. Smaller fruits were dominant in bunches, averaging 8.2 fruits per day (70\%), while the median size ones 
were less frequent (averaging 2.2 fruits, or 19\%) and the big ones were rare (1.2 fruits, or $11 \%)(\mathrm{N}=328$ fruits sampled).

Nocturnal and the diurnal assemblage of vertebrates partitioned the fruits similarly $(\mathrm{P}=0.77): 2.9 \%$ of fruit removal per night ( $\mathrm{N}$ total $=328$ fruits from 28 bunches) versus $2.5 \%$ per day $(\mathrm{N}$ total $=265$ from 23 bunches). Recent predated ripe fruits (by insects) were poorly removed, independently of fruit size or time of removal. However, from the total fruits removed during the day $(\mathrm{N}=20)$, $45 \%$ were big, $50 \%$ were medium, $65 \%$ were yellowish, 35\% were big-yellowish and 30\% were medium-yellowish. From the total fruits removed in the night $(\mathrm{N}=38), 32 \%$ were big, $35 \%$ were median sized-fruits, $40 \%$ were yellowish and $26 \%$ were big-yellowish. Fallen fruits were mainly those smaller (small: $70 \%$, median: $23 \%$, and big: $6 \%$; $\mathrm{N}_{1}=47$ fallen fruits; $\mathrm{N}_{2}=14$ days of observations) or of green color $(66 \%)$. The big-yellowish fruits were seldom seen fallen on the ground (only 6\%).

Nine species of vertebrates, namely birds (Saltator similis Lafresnaye \& d'Orbigny, $1837-\mathrm{N}=8$ observations; Thraupis sayaca (Linnaeus, 1766) $-\mathrm{N}=7$ ), bats (Artibeus lituratus (Olfers, $1818)-\mathrm{N}=3$ captures; Sturnira lilium (E. Geoffroy, 1810) $-\mathrm{N}=$ 2; Pygoderma bilabiatum (Wagner, 1843) $-\mathrm{N}=2$ ), rodents (Akodon paranaensis Christoff et al., $2000-\mathrm{N}=1$ capture; Cavia aperea Erxleben $-\mathrm{N}=1$; Oligoryzomys nigripes (Wagner, 1845) $-\mathrm{N}=1$ ), and a marsupial (Didelphis albiventris Lund, $1840-\mathrm{N}=3$ captures), were registered removing fruits of $S$. granulosoleprosum.

Because small and green fruits were the most fallen fruits observed on the ground below $S$. granulosoleprosum plants, observed rates of fruit removal were validated mainly for bigger and yellowish fruits which were truly removed by vertebrates rather than were fallen on the ground. Solanum granulosoleprosum produces a few ripe fruits (about two per bunch) every day probably to maximize the effort of seed dispersal, assuring that most fruits produced are consumed by dispersers without wasting, and avoiding seed predators such as ants, beetles and grasshoppers (e.g. LeVEy \& BYrNe 1993) that could be attracted with a high, daily, fruit production.

The vertebrate assemblage removing fruits of $S$. granulosoleprosum is composed by animals common in disturbed, urban, environments. This assemblage is mostly frugivorous, being probably seed dispersers of this wild tomato species (Marcondes-Machado \& Oliveira 1988, Müller \& Reis 1992, Reis et al. 1993, Galetti \& Morellato 1994, Poulin et al. 1994, Sazima et al. 1994, CÁCERES 2002), except for small rodents that are most probably seed predators (e.g. Perry \& Fleming 1980, Janzen 1982). However, small rodents are expected to disperse only small seeds $(<5 \mathrm{~mm})$ such as Miconia albicans (Sw.) Triana (MAGNusson \& SANAIOTTI 1987). Additionally, birds, bats and terrestrial small mammals make different types of seed rain in the forest (Fleming \& Heithaus 1981, Charles-Dominique 1986), showing that $S$. granulosoleprosum seeds are capable to be dispersed to a wide range of environments.

The green-yellowish fruits of $S$. granulosoleprosum attract nocturnal (bats, marsupials and murid rodents) as well as diurnal (birds and caviomorph rodents) consumers at similar rates, differently of Renealmia alpina (Rottb.) Maas. (Zingiberaceae) fruits in a gallery forest of central Brazil that attract only small rodents (BIZERRIL \& GASTAL 1997). Here, diurnal removers (e.g. birds) tended to feed mainly on big, ripe fruits while nocturnal removers (e.g. bats) fed mostly also on median-sized fruits, maybe due to the different strategies to explore resources present in both groups (mostly vision and echolocation/olfactory cue, respectively). In our study, the green-yellowish color of $S$. granulosoleprosum fruits, besides their strategic position in the plant, was capable to attract very different seed consumers, similarly as does Cecropia (CHARLes-DominiQue 1986).

Thus the exposed outside crown of $S$. granulosoleprosum fruits should facilitate to flying dispersers to remove them during the flight (VAN DER PIJL 1982). However, terrestrial small mammals should climb the plant to find fruits, as was seen twice for rodents (probably $O$. nigripes) in this study, since median size to big, ripe fruits are usually not available on the soil.

Solanum granulosoleprosum does not appear to belong strongly to any known dispersal syndrome because the different fauna attracted by their fruits, showing a broad strategy of seed dispersal.

\section{ACKNOWLEDGMENTS}

We are in debt with many persons that helped us in the field and in the species determination such as V.J. Rocha, M.L. Sekiama (bats), I.J. Sbalqueiro (rodents), M. Pichorim, M.R. Bornschein (birds), J. Quadros, M.O. Bordignon and V.A.O. Dittrich. E.L.A. Monteiro-Filho and F. Passos reviewed the manuscript. This work was partly supported by CAPES (NCC).

\section{REFERENCES}

Bizerril, M.X. \& M.L. Gastal. 1997. Fruit phenology and mammal frugivory in Renealmia alpinia (Zingiberaceae) in a gallery forest of central Brazil. Revista Brasileira de Biologia, Rio de Janeiro, 57 (2): 305-309.

CÁCERES, N.C. 2002. Food habits and seed dispersal by the whiteeared opossum, Didelphis albiventris, in southern Brazil. Studies on Neotropical Fauna \& Environment, Lisse, 37: 97-104.

ChARLES-Dominique, P. 1986. Inter-relations between frugivorous vertebrates and pioneer trees: Cecropia, birds and bats in French Guiana, p. 119-134. In: A. Estrada \& T.H. Fleming (Eds). Frugivores and seed dispersal. Dordrecht, Dr. W. Junk, 392p.

Fleming, T.H. \& E.R. Heithaus. 1981. Frugivorous bats, seed shadows, and the structure of tropical forests. Biotropica, Lawrence, 13 (Suppl.): 45-53.

Galetti, M. \& P.C. Morellato. 1994. Diet of the fruit-eating bat Artibeus lituratus in a forest fragment in Brasil. Mammalia, Paris, 58 (4): 661-665.

Howe, H.F. \& J. Smallwood. 1982. Ecology of seed dispersal. Annual Review of Ecology and Systematic, Palo Alto, 13: 201-228.

JANZEN, D.H. 1982. Seed removal from fallen guanacaste fruits (Enterolobium cyclocarpum) by spiny pocket mice (Liomys salvini). Brenesia, San José, 19/20: 425-429.

Levey, D.J. \& M.M. Byrne. 1993. Complex ant-plant interactions: rain forest ants as secondary dispersers and post-dispersal seed predators. Ecology, Washington, 74: 1802-1812.

Magnusson, W.E. \& T.M. SanaiotTi. 1987. Dispersal of Miconia seeds by the rat Bolomys lasiurus. Journal of Tropical Ecology, Cambridge, 3: 277-278,

Marcondes-Machado, L.O. \& M.M.A. Oliveira. 1988. Comportamento alimentar de aves em Cecropia (Moraceae), em Mata

Revista Brasileira de Zoologia 20 (3): 519-522, setembro 2003 
Atlântica, no Estado de São Paulo. Revista Brasileira de Zoologia, Curitiba, 4 (4): 331-339.

MülleR, M.F. \& N.R. ReIs. 1992. Partição de recursos alimentares entre quatro espécies de morcegos frugívoros (Chiroptera, Phyllostomidae). Revista Brasileira de Zoologia, Curitiba, 9 (3/4): 345-355.

Perry, A.E. \& T.H. Fleming. 1980. Ant and rodent predation on small, animal-dispersed seeds in a dry tropical forest. Brenesia, San José, 17: 11-22.

Poulin, B.; G. Lefebvre \& R. McneIL. 1994. Characteristics of feeding guilds and variation in diets of bird species of three adjacent tropical sites. Biotropica, Lawrence, 26 (2): 187-197.
Reis, N.R.; A.L. Peracchi \& M.A. Onuki. 1993. Quirópteros de Londrina. Paraná, Brasil (Mammalia, Chiroptera). Revista Brasileira de Zoologia, Curitiba, 10 (3): 371-381.

SAzima, I.; W.A. Fischer; M. SAZima \& E.A. Fischer. 1994. The fruit bat Artibeus lituratus as a forest and city dweller. Ciência e Cultura, São Paulo, 46 (3): 164-168.

Smithe, N. 1970. Relationships between fruiting seasons and seed dispersal methods in a neotropical forest. American Naturalist, Chicago, 104 (935): 25-35.

Statistica FOR Windows. 1993. Release 4.2 (A). StatSoft, USA.

VAN DER PIJL, L. 1982. Principles of dispersal in higher plants. Berlin, Springer-Verlag, X+215p.

Received in 14.III.2003; accepted in 27.VIII.2003.

Revista Brasileira de Zoologia 20 (3): 519-522, setembro 2003 